\title{
Dietary net energy levels for growing barrows from 30 to $70 \mathrm{~kg}$
}

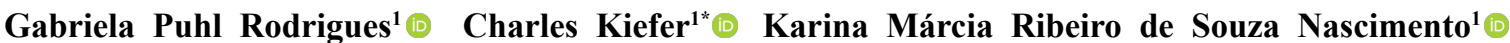 Anderson Corassa ${ }^{2}$ (i) Danilo Alves Marçal $^{1}$ (i) Marina de Nadai Bonin ${ }^{1}$ (iD Alexandre Pereira dos Santos $^{1}$ (D) Luana Cristiane dos Santos $^{1}$ (D)}

\begin{abstract}
${ }^{1}$ Programa de Pós-graduação em Ciência Animal, Universidade Federal de Mato Grosso do Sul (UFMS), 79070-900, Campo Grande, MS, Brasil. E-mail: charles.kiefer@ufms.br. "Corresponding author.

${ }^{2}$ Universidade Federal de Mato Grosso (UFMT), Sinop, MT, Brasil.

ABSTRACT: This study evaluated the effect of dietary net energy (NE) levels on growth performance and carcass characteristics of barrows from 30 to $70 \mathrm{~kg}$ of body weight (BW). Sixty barrows with initial body weight (IBW) of $31.94 \pm 3.54 \mathrm{~kg}$ and final body weight (FBW) of $71.98 \pm$ $5.99 \mathrm{~kg}$ were allotted to one of five dietary $\mathrm{NE}$ levels $\left(2.40,2.45,2.50,2.55\right.$, and $\left.2.60 \mathrm{Mcal} \mathrm{kg}^{-1}\right)$, using a completely randomized block design with six replicates and two barrows per replicate. The experimental period was divided into phase I: 30 to $50 \mathrm{~kg}$ and phase II: 50 to $70 \mathrm{~kg}$. The variables analyzed were average daily feed intake (ADFI), net energy intake (NEI), digestible lysine intake (LysI), average daily gain (ADG), feed conversion (FC), FBW, digestible lysine conversion:gain (LysI:G), Cost:Gain (C:G), loin eye area (LEA), muscle depth (MD), first backfat layer $\left(B F_{1}\right)$, second backfat layer $\left(B F_{2}\right)$, total backfat (BFt), lean meat percentage, and carcass bonus index (BI). In phase I, there was a linear increase $(P<0.05)$ in FBW, ADG, NEI, and LysI with increasing NE levels in the diet. In phase II, increasing dietary NE levels also increased $(P<0.05) F B W, A D G, N E I, L y s I$, and FC linearly. Overall, there was a linear increase $(P<0.05)$ in ADG, NEI, LysI, and FC with increasing $N E$ levels in the diet. The other performance variables were not affected $(P>0.05)$ by the NE levels. There was an increase $(P<0.05)$ in $B F{ }_{2}$ with increasing NE levels, but the other carcass characteristics were not altered $(P>0.05)$. We recommended $2.60 \mathrm{Mcal}_{\mathrm{of}} \mathrm{NE} \mathrm{kg}^{-1}$ in the diet for growing barrows from 30 to $70 \mathrm{~kg}$.
\end{abstract}

Keywords: calorie:nutrient ratio, energy intake, nutritional density, requirements.

Níveis de energia líquida para suínos machos castrados dos 30 aos $70 \mathrm{~kg}$

RESUMO: Realizou-se este estudo com o objetivo de avaliar níveis de energia líquida (EL), mantendo a relação caloria: nutriente, no desempenho e características de carcaça de suínos dos 30 aos $70 \mathrm{~kg}$. Foram utilizados 60 suínos machos castrados, com pesos iniciais de $31,94 \pm 3,54 \mathrm{~kg}$ e finais de 71,98 $\pm 5,99 \mathrm{~kg}$. Os animais foram distribuidos em delineamento experimental de blocos casualizados, em cinco niveis de EL $(2,40 ; 2,45 ; 2,50 ; 2,55 ; 2,60 \mathrm{Mcal}$ de $E L \mathrm{~kg}-1$ de dieta), com seis repetições e dois animais por unidade experimental. O periodo experimental foi dividido em fase I: 30 aos $50 \mathrm{~kg}$ e fase II: 50 aos $70 \mathrm{~kg}$. As variáveis analisadas foram os consumos de ração diária (CRD), energia líquida (CEL) e lisina digestível (CLdig), ganho de peso diário (GPD), conversão alimentar (CA), peso final (PF), conversão de lisina digestivel: ganho (CLdig:G), custo: ganho (C:G), área de olho de lombo (AOL), profundidade de músculo (PM), espessura de toucinho da primeira camada (ET1), espessura de toucinho da segunda camada (ET2), espessura de toucinho total (ETt), percentual de carne magra (CM) e o índice de bonificação de carcaça (IB). Dos 30 aos $50 \mathrm{~kg}$, verificou-se aumento linear $(P<0,05)$ do PF, GPD e dos CEL e CLdig com o aumento dos níveis de EL na dieta. Dos 50 aos $70 \mathrm{~kg}$, o aumento dos niveis de EL na dieta promoveu melhora linear (P < 0,05) do PF, GPD, $C E L, C L d i g$ e da CA dos suínos. No periodo total, verificou-se aumento linear $(P<0,05)$ do GPD, CEL, CLdig e melhora linear $(P<0,05)$ da $C A$ de acordo com o aumento do nível de EL na dieta. As demais variáveis de desempenho não foram afetadas $(P>0,05)$ pelos níveis de EL. Verificou-se aumento $(P<0,05)$ da ET2 de acordo com o aumento do nível de EL, porém sem alterar $(P>0,05)$ as demais características de carcaça. Recomenda-se o nível 2,60 Mcal de EL kg-1 de dieta para suínos machos castrados dos 30 aos $70 \mathrm{~kg}$.

Palavras-chave: caloria: nutriente, consumo de energia, exigências, densidade nutricional.

\section{INTRODUCTION}

Considering the important relationships that dietary energy has with costs (NOBLET, 2007), growth performance, and carcass characteristics (QUINIOU \& NOBLET, 2012), several studies were developed to establish the ideal level of dietary energy for pigs (QUINIOU \& NOBLET, 2012; NITIKANCHANA et al., 2015; SMITH et al., 2017; MARÇAL et al., 2018a, b; MARÇAL et al., 2019). One of the strategies adopted by nutritionists is the formulation of diets based on the net energy

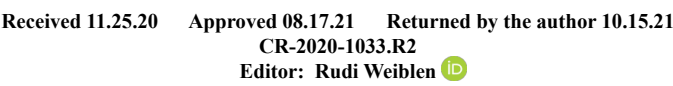


(NE) values of the feedstuffs. Using the NE system allows for better precision in diet formulation by adjusting for differences in nutrient metabolism, and accurately describing the actual nutritional content of the ingredients (SAKOMURA \& ROSTAGNO, 2016). In the growing and finishing phases, studies indicated that increasing the dietary energy level decreases the average daily feed intake (ADFI) and improves feed conversion of the pigs (CÁMARA et al., 2014, 2016; GONÇALVES et al., 2015; MARÇAL et al., 2018a,b). However, increasing the dietary energy density without maintaining a constant energy:nutrient ratio may not simultaneously improve the average daily gain (ADG) and increase carcass fat deposition, since the availability of essential amino acids may not be sufficient for protein synthesis. This would limit both the ADG and the extent to which excess energy consumed can be deposited as fat in the carcass (MARÇAL et al., 2019).

In addition, with the genetic improvement of pigs, it is constantly necessary to re-evaluate the dietary nutritional levels, as evidenced by the increase in the nutritional requirement for metabolizable energy (ME) (0.12 Mcal kg-1) when comparing the last two Brazilian Tables for Poultry and Swine (ROSTAGNO et al., 2011, 2017). For these reasons, this study evaluated the effect of dietary NE levels, while maintaining the calorie:nutrient ratio, on growth performance and carcass characteristics for pigs from 30 to $70 \mathrm{~kg}$, with the aim to reduce production costs and optimize growth performance.

\section{MATERIALS AND METHODS}

Sixty commercial hybrid barrows that were genetically similar, with initial body weights (IBW) and final body weights (FW) of $31.94 \pm 3.54$ $\mathrm{kg}$ and $71.98 \pm 5.99 \mathrm{~kg}$ respectively, were used. Two animals were housed per pen, each of which had a density of $1.47 \mathrm{~m}^{2} \mathrm{head}^{-1}$, a concrete floor, and a water pool; and pens were equipped with semi-automatic feeders and nipple drinkers.

Experimental treatments were allocated to pigs in a randomized block design, with five dietary NE levels $\left(2.40 ; 2.45 ; 2.50 ; 2.55 ; 2.60 \mathrm{Mcal} \mathrm{kg}^{-1}\right.$ of diet), six replications per treatment and two pigs per experimental pen. Initial BW was adopted as the criteria for the formation of the blocks and each pen was considered as the experimental unit.

The experimental diets (Tables 1 and 2) were formulated, based on the ideal protein concept, to meet the nutritional requirements of high genetic potential barrows with superior growth performance
(ROSTAGNO et al., 2017). The increases in the NE density of the diets were achieved by the inclusion of soybean oil as a replacement for kaolin (inert). The calorie:nutrient ratio, except for the $\mathrm{Na}$ levels, was kept constant across all diets through the inclusion of isolated amino acids, limestone, and dicalcium phosphate to replace kaolin.

The diets, in meal form, were fed ad libitum and the animals had free access to water throughout the experimental period, which lasted 40 days and was divided in two experimental phases (phase I: 30 to $50 \mathrm{~kg}$, and phase II: 50 to $70 \mathrm{~kg}$ ). Feed waste was collected and added to the feeder leftovers at the end of each experimental phase, to determine average daily feed intake (ADFI), average daily NE intake (NEI), and average daily digestible lysine intake (LysI).

The environmental conditions inside the barn were monitored using a maximum and minimum thermometer and a portable digital thermometer (model ITWTG 2000), from which dry bulb temperature, wet bulb temperature, black globe temperature, and air relative humidity were recorded daily at 8 A.M. and 4 P.M. The black globe temperature and relative humidity index (BGHI) was calculated using the equation proposed by BUFFINGTON et al. (1981).

The ADFI was determined from the subtraction of the collected waste from the feed provided. The NEI and the LysI were obtained by multiplying the feed intake in the phase by their respective contents in each diet. The pigs were weighed in an electronic scale at the beginning and end of each experimental phase to determine their average daily gain (ADG) and FBW. LysI:G was calculated by dividing the LysI by the ADG for each phase. Feed conversion (FC) was calculated by dividing the ADFI by the ADG.

An economic analysis of the studied diets was performed to determine the Cost:G (C:G), using the equation adapted from BELLAVER et al. (1985): $\mathrm{Yi}=(\mathrm{Qi} \times \mathrm{Pi}) / \mathrm{Gi}$, where $\mathrm{Yi}=$ feed cost per kilogram of pig gain mass in the $\mathrm{i}$-th treatment; $\mathrm{Qi}=$ amount of feed consumed in the $\mathrm{i}$-th treatment; $\mathrm{Pi}=$ price per kilogram of feed used in the $\mathrm{i}$-th treatment; and $\mathrm{Gi}=$ BW gain in the $\mathrm{i}$-th treatment.

At the end of the experimental period, quantitative carcass characteristics measurements were obtained by in vivo ultrasonography. The ultrasound device ALOKA SSD $500 \mathrm{~V}$ was used, with an acoustic probe of $12 \mathrm{~cm}$ and frequency of 3.5 Mhz. To allow the proper coupling of the transducer with the body of the pig, a silicone coupler was used, which follows the arching of the ribs, and soy oil was used to avoid the presence of air between the probe 
Table 1 - Centesimal and nutritional composition of experimental diets (30 to $50 \mathrm{~kg})$.

\begin{tabular}{|c|c|c|c|c|c|}
\hline \multirow[t]{2}{*}{ Ingredients, $\%$} & \multicolumn{5}{|c|}{ 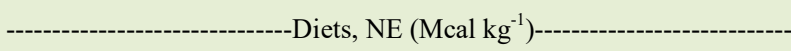 } \\
\hline & 2.40 & 2.45 & 2.50 & 2.55 & 2.60 \\
\hline Corn $(7.88 \%)$ & 65.96 & 65.96 & 65.96 & 65.96 & 65.96 \\
\hline Soybean meal (46.5\%) & 26.74 & 26.74 & 26.74 & 26.74 & 26.74 \\
\hline Kaolin (inert) & 3.200 & 2.427 & 1.657 & 0.888 & 0.115 \\
\hline Soybean oil & 0.977 & 1.632 & 2.288 & 2.944 & 3.599 \\
\hline Dicalcium phosphate & 1.347 & 1.397 & 1.448 & 1.498 & 1.548 \\
\hline Limestone & 0.662 & 0.669 & 0.673 & 0.678 & 0.685 \\
\hline L-Lysine $\mathrm{HCl}$ & 0.277 & 0.305 & 0.333 & 0.360 & 0.388 \\
\hline L-Threonine & 0.094 & 0.108 & 0.123 & 0.138 & 0.153 \\
\hline DL-Methionine & 0.100 & 0.113 & 0.126 & 0.138 & 0.151 \\
\hline L-Tryptophan & 0.014 & 0.020 & 0.023 & 0.027 & 0.032 \\
\hline Vitamin-mineral premix ${ }^{1}$ & 0.150 & 0.150 & 0.150 & 0.150 & 0.150 \\
\hline Tiamulin & 0.050 & 0.050 & 0.050 & 0.050 & 0.050 \\
\hline Salt & 0.432 & 0.432 & 0.432 & 0.432 & 0.432 \\
\hline \multicolumn{6}{|c|}{ 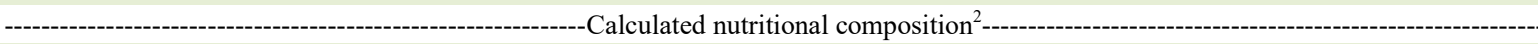 } \\
\hline Net energy, Mcal kg${ }^{-1}$ & 2.40 & 2.45 & 2.50 & 2.55 & 2.60 \\
\hline Metabolizble energy, Mcal kg ${ }^{-1}$ & 3.19 & 3.24 & 3.30 & 3.36 & 3.42 \\
\hline Crude protein, $\%$ & 18.00 & 18.05 & 18.09 & 18.14 & 18.19 \\
\hline SID lysine, $\%$ & 1.026 & 1.048 & 1.069 & 1.090 & 1.112 \\
\hline SID met+cys, $\%$ & 0.605 & 0.618 & 0.631 & 0.643 & 0.656 \\
\hline SID threonine, $\%$ & 0.667 & 0.681 & 0.695 & 0.709 & 0.723 \\
\hline SID tryptophan, $\%$ & 0.205 & 0.210 & 0.214 & 0.218 & 0.222 \\
\hline Calcium, \% & 0.693 & 0.708 & 0.722 & 0.736 & 0.751 \\
\hline Digestible phosphorus, $\%$ & 0.332 & 0.339 & 0.346 & 0.353 & 0.360 \\
\hline Sodium, $\%$ & 0.190 & 0.190 & 0.190 & 0.190 & 0.190 \\
\hline
\end{tabular}

${ }^{1}$ Content per $\mathrm{kg}$ of diet: panthotenic acid: $9.2 \mathrm{mg}$; niacin: $18.0 \mathrm{mg}$; folic acid: $0.5 \mathrm{mg}$; copper: $15.0 \mathrm{mg}$; iron: $0.1 \mathrm{mg}$; zinc: $0.1 \mathrm{mg}$; iodine: $1.0 \mathrm{mg}$; selenium: $0.3 \mathrm{mg}$; manganese: $0.5 \mathrm{mg}$; vitaminA: 5,000 IU; vitamin D3: 1,000 IU; vitamin E: $25.0 \mathrm{IU}$; vitamin K3: 3.0 $\mathrm{mg}$; vitamin B1: $1.5 \mathrm{mg}$; vitamin B2: $4.0 \mathrm{mg}$; vitamin B6: $1.5 \mathrm{mg}$; vitamin B12: $18.0 \mathrm{mg}$; BHT: $1.0 \mathrm{~g}$ and vehicle: $1,0 \mathrm{~g}$.

${ }^{2}$ Values calculated according to Rostagno et al. (2017).

and the skin. The probe was placed between the last thoracic and the first lumbar vertebra (Point P2). All images collected were analyzed using the $\operatorname{LINCE}^{\circledR}$ program. Lean percentage and bonification index (BI) values were determined according to the equations: Lean $(\%)=(60-($ backfat thickness $\times 0.58)+$ loin depth $\times 0.10)$ and $\mathrm{BI}=(23.6+(0.286 \times$ hot carcass weight) + lean \%).

The variables analyzed were ADFI, NEI and LysI, ADG, FC, FW, LysI:G, C:G, loin eye area (LEA), muscle depth (MD), first backfat layer $\left(\mathrm{BF}_{1}\right)$, second backfat layer $\left(\mathrm{BF}_{2}\right)$ and total backfat thickness $\left(\mathrm{BF}_{\mathrm{t}}\right)$, lean percentage, and BI. Data were submitted to analysis of variance and linear and quadratic regression analysis to determine the effects of dietary NE levels at the 5\% probability level. Statistical analyses were performed in SAS version 9.1 (SAS, 2004).

\section{RESULTS}

The mean environmental air temperature verified during the experimental period was $26.96 \pm$ $3.7{ }^{\circ} \mathrm{C}$; the relative air humidity averaged $55.59 \% \pm$ $20.2 \%$, the black globe temperature $27.19 \pm 3.6^{\circ} \mathrm{C}$, and the BGHI $75.48 \pm 3.9$.

In the first phase of the study, from 30 to $50 \mathrm{~kg}$, there was a linear increase $(\mathrm{P}<0.05)$ in FBW, ADG, NEI, and LysI with increasing dietary NE levels. However, there were no effects $(\mathrm{P}>0.05)$ of dietary NE on ADFI, FC, and LysI:G (Table 3).

In the second phase, from 50 to $70 \mathrm{~kg}$, there was a linear increase $(\mathrm{P}<0.05)$ in FBW, ADG, NEI, and LysI, and a linear improvement $(\mathrm{P}<0.05)$ in FC with increasing dietary NE levels. In this phase, NE levels did not affect $(\mathrm{P}>0.05)$ ADFI and LysI:G (Table 3). 
Table 2 - Centesimal and nutritional composition of experimental diets (50 to $70 \mathrm{~kg}$ ).

\begin{tabular}{|c|c|c|c|c|c|}
\hline \multirow[t]{2}{*}{ Ingredients, \% } & \multicolumn{5}{|c|}{ - } \\
\hline & 2.40 & 2.45 & 2.50 & 2.55 & 2.60 \\
\hline Corn $(7.88 \%)$ & 73.49 & 73.49 & 73.49 & 73.49 & 73.49 \\
\hline Soybean meal (46.5\%) & 20.61 & 20.61 & 20.61 & 20.61 & 20.61 \\
\hline Kaolin (inert) & 3.371 & 2.617 & 1.864 & 1.112 & 0.354 \\
\hline Soybean oil & 0.000 & 0.659 & 1.318 & 1.977 & 2.635 \\
\hline Dicalcium phosphate & 0.917 & 0.953 & 0.996 & 1.032 & 1.076 \\
\hline Limestone & 0.594 & 0.603 & 0.604 & 0.610 & 0.614 \\
\hline L-Lysine $\mathrm{HCl}$ & 0.271 & 0.294 & 0.317 & 0.340 & 0.365 \\
\hline L-Threonine & 0.073 & 0.085 & 0.098 & 0.111 & 0.123 \\
\hline DL-Methionine & 0.062 & 0.072 & 0.083 & 0.094 & 0.105 \\
\hline L-Tryptophan & 0.017 & 0.021 & 0.024 & 0.028 & 0.032 \\
\hline Vitamin-mineral premix ${ }^{1}$ & 0.150 & 0.150 & 0.150 & 0.150 & 0.150 \\
\hline Tiamulin & 0.050 & 0.050 & 0.050 & 0.050 & 0.050 \\
\hline Salt & 0.396 & 0.396 & 0.396 & 0.396 & 0.396 \\
\hline \multicolumn{6}{|c|}{ 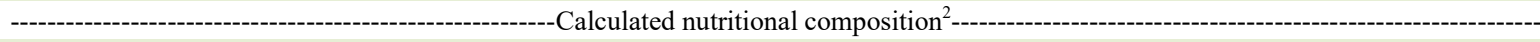 } \\
\hline Net energy, Mcal kg-1 & 2.40 & 2.45 & 2.50 & 2.55 & 2.60 \\
\hline Metabolizble energy, Mcal kg ${ }^{-1}$ & 3.16 & 3.21 & 3.27 & 3.33 & 3.38 \\
\hline Crude protein, $\%$ & 15.70 & 15.74 & 15.78 & 15.82 & 15.86 \\
\hline SID lysine, $\%$ & 0.876 & 0.894 & 0.912 & 0.930 & 0.949 \\
\hline SID met+cys, $\%$ & 0.517 & 0.527 & 0.538 & 5.49 & 0.560 \\
\hline SID threonine, $\%$ & 0.569 & 0.581 & 0.593 & 0.605 & 0.617 \\
\hline SID tryptophan, $\%$ & 0.175 & 0.179 & 0.182 & 0.186 & 0.190 \\
\hline Calcium, \% & 0.543 & 0.555 & 0.566 & 0.577 & 0.589 \\
\hline Digestible phosphorus, $\%$ & 0.264 & 0.269 & 0.275 & 0.280 & 0.286 \\
\hline Sodium, $\%$ & 0.176 & 0.176 & 0.176 & 0.176 & 0.176 \\
\hline
\end{tabular}

${ }^{1}$ Content per $\mathrm{kg}$ of diet: panthotenic acid: $9.2 \mathrm{mg}$; niacin: $18.0 \mathrm{mg}$; folic acid: $0.5 \mathrm{mg}$; copper: $15.0 \mathrm{mg}$; iron: $0.1 \mathrm{mg}$; zinc: $0.1 \mathrm{mg}$; iodine: $1.0 \mathrm{mg}$; selenium: $0.3 \mathrm{mg}$; manganese: $0.5 \mathrm{mg}$; vitaminA: $5,000 \mathrm{IU}$; vitamin D3: 1,000 IU; vitamin E: $25.0 \mathrm{IU}$; vitamin K3: 3.0 $\mathrm{mg}$; vitamin B1: $1.5 \mathrm{mg}$; vitamin B2: $4.0 \mathrm{mg}$; vitamin B6: $1.5 \mathrm{mg}$; vitamin B12: $18.0 \mathrm{mg}$; BHT: $1.0 \mathrm{~g}$ and vehicle: $1,0 \mathrm{~g}$.

${ }^{2}$ Values calculated according to Rostagno et al. (2017).

Overall, from 30 to $70 \mathrm{~kg}$, there was a linear increase $(\mathrm{P}<0.05)$ in ADG, NEI, and LysI and a linear improvement $(\mathrm{P}<0.05)$ in $\mathrm{FC}$ with increasing dietary NE levels. However, ADFI, LysI:G, and C:G were not affected $(\mathrm{P}>0.05)$ by dietary NE.

Among carcass characteristics, there was a linear increase $(\mathrm{P}<0.05)$ in $\mathrm{BF}_{2}$ with increasing dietary NE levels. No other carcass characteristics were affected $(\mathrm{P}>0.05)$ by the experimental diets (Table 4$)$.

\section{DISCUSSION}

The average air temperature recorded during the study was above the upper critical temperature of $22^{\circ} \mathrm{C}$ (RENAUDEAU et al., 2011). In addition, the BGHI was above that of 69.6 observed in studies with pigs under thermal comfort conditions (KIEFER et al., 2010). However, considering the
ADFI and ADG observed in the present study, when compared to the standards for high genetic potential barrows with medium-superior growth performance (namely, 1.71 and $2.34 \mathrm{~kg}$ for ADFI, and 0.93 and $1.05 \mathrm{~kg}$ for $\mathrm{ADG}$, from 30 to $50 \mathrm{~kg}$ and from 50 to 70 $\mathrm{kg}$, respectively), established by ROSTAGNO et al. (2017), it can be inferred that the thermal conditions did not influence the growth performance of the pigs.

Considering the evaluated NE levels, it was expected that the difference of $0.20 \mathrm{Mcal} \mathrm{\textrm { } \mathrm { g } ^ { - 1 }}$ between the minimum and maximum levels that were studied (2.40 and 2.60 Mcal kg-1, respectively) would provide an effect on the ADFI, as studies indicate that pigs are able to adjust their voluntary feed intake in response to changes in the nutritional density of the diet (NYACHOTI et al., 2004; LI \& PATIENCE, 2017). Usually, high levels of dietary energy result in a reduction in the ADFI of growing-finishing pigs

Ciência Rural, v.52, n.7, 2022. 
Table 3 - Growth performance of barrows from 30 to $70 \mathrm{~kg}$ fed with diets with different net energy levels.

\begin{tabular}{|c|c|c|c|c|c|c|c|c|}
\hline \multirow[t]{2}{*}{ Variables } & \multicolumn{5}{|c|}{----------------------Diets, NE (Mcal kg ${ }^{-1}$ )----------------------- } & \multicolumn{2}{|c|}{---------P value--------- } & \multirow[t]{2}{*}{$\mathrm{CV}, \%$} \\
\hline & 2.40 & 2.45 & 2.50 & 2.55 & 2.60 & $\mathrm{~L}$ & Q & \\
\hline \multicolumn{9}{|c|}{ - } \\
\hline IBW, $\mathrm{kg}$ & 32.01 & 31.91 & 31.97 & 31.99 & 31.83 & 0.129 & 0.133 & 3.21 \\
\hline FBW, kg ${ }^{*}$ & 49.46 & 49.43 & 49.68 & 49.82 & 49.89 & 0.020 & 0.250 & 3.14 \\
\hline $\mathrm{ADG}, \mathrm{kg}^{*}$ & 0.92 & 0.92 & 0.93 & 0.94 & 0.95 & 0.027 & 0.785 & 5.33 \\
\hline AADFI, kg & 1.90 & 1.91 & 1.95 & 1.89 & 1.86 & 0.953 & 0.131 & 6.81 \\
\hline $\mathrm{FC}$ & 2.07 & 2.07 & 2.09 & 2.01 & 1.96 & 0.055 & 0.133 & 6.20 \\
\hline NEI, Mcal d ${ }^{-1^{*}}$ & 4.56 & 4.69 & 4.87 & 4.81 & 4.84 & 0.006 & 0.129 & 6.94 \\
\hline LysI, g d $^{-1^{*}}$ & 19.50 & 20.06 & 20.82 & 20.56 & 20.71 & 0.006 & 0.127 & 6.95 \\
\hline LysI:G & 21.22 & 21.71 & 22.35 & 21.91 & 21.79 & 0.208 & 0.136 & 6.32 \\
\hline \multicolumn{9}{|c|}{ - } \\
\hline BFW kg** & 71.11 & 70.68 & 72.10 & 72.88 & 73.32 & 0.001 & 0.655 & 3.59 \\
\hline $\mathrm{ADG}, \mathrm{kg}^{* *}$ & 1.03 & 1.01 & 1.07 & 1.10 & 1.12 & $<0.001$ & 0.698 & 6.84 \\
\hline AADFI, kg & 2.65 & 2.59 & 2.67 & 2.70 & 2.66 & 0.395 & 0.817 & 8.91 \\
\hline $\mathrm{FC}^{* *}$ & 2.56 & 2.55 & 2.51 & 2.46 & 2.38 & $<0.001$ & 0.222 & 4.43 \\
\hline NEI, Mcal d ${ }^{-1 * *}$ & 6.35 & 6.34 & 6.68 & 6.89 & 6.92 & 0.003 & 0.835 & 9.02 \\
\hline LysI, $\mathrm{g} \mathrm{d}^{-1^{* *}}$ & 23.19 & 23.13 & 24.35 & 25.14 & 25.24 & 0.003 & 0.840 & 9.01 \\
\hline LysI:G & 22.46 & 22.84 & 22.85 & 22.90 & 22.53 & 0.722 & 0.196 & 4.45 \\
\hline \multicolumn{9}{|c|}{ - } \\
\hline $\mathrm{ADG}, \mathrm{kg}^{* * *}$ & 0.98 & 0.97 & 1.00 & 1.02 & 1.04 & $<0.001$ & 0.817 & 4.73 \\
\hline AADFI, kg & 2.29 & 2.27 & 2.33 & 2.31 & 2.28 & 0.564 & 0.504 & 7.66 \\
\hline $\mathrm{FC}^{* * *}$ & 2.33 & 2.33 & 2.31 & 2.25 & 2.18 & $<0.001$ & 0.096 & 4.31 \\
\hline NEI, Mcal d ${ }^{-1 * * *}$ & 5.50 & 5.56 & 5.82 & 5.90 & 5.93 & 0.002 & 0.502 & 7.80 \\
\hline LysI, $\mathrm{g} \mathrm{d}^{-1 * * *}$ & 21.44 & 21.67 & 22.68 & 22.97 & 23.09 & 0.003 & 0.470 & 7.70 \\
\hline LysI:G & 21.90 & 22.32 & 22.62 & 22.43 & 22.19 & 0.328 & 0.094 & 4.37 \\
\hline Cost:G, R\$ & 0.20 & 0.21 & 0.20 & 0.20 & 0.20 & 0.167 & 0.401 & 4.76 \\
\hline
\end{tabular}

NE: Net Energy; IBW: Initial Body Weight; FBW: Final Body Weight;ADG: Average Daily Gain; AADFI: Average Dily Feed Intake; FC: Feed Conversion; NEI: Average Daily Net Energy Intake; LysI: Average Daily Digestible Lysine Intake; LysI:G: Average Daily Digestible Lysine Intake:G; Cost:G: Diet Cost per kg of Diet; L: Linear Effect; Q: Quadratic Effect; CV: Coeficient of Variation.

${ }^{*}$ Linear effect (Phase I, 30 to $50 \mathrm{~kg}$ ): FBW, Y = 0.0025x $+43.393, \mathrm{R}^{2}=0.91$; ADG, $\mathrm{Y}=0.0002 \mathrm{x}+0.535, \mathrm{R}^{2}=0.97$; NEI, Y $=0.0014 \mathrm{x}$ $+1.350, \mathrm{R}^{2}=0.71 ;$ LysI, $\mathrm{Y}=0.0058 \mathrm{x}+5.724, \mathrm{R}^{2}=0.71$

${ }^{* *}$ Linear effect (Phase II, 50 to $70 \mathrm{~kg}$ ): FBW, $\mathrm{Y}=0.0133 \mathrm{x}+38.886, \mathrm{R}^{2}=0.87$; ADG, $\mathrm{Y}=0.0005 \mathrm{x}-0.205, \mathrm{R}^{2}=0.87 ; \mathrm{FC}, \mathrm{Y}=-0.0009 \mathrm{x}$ $+4.815, \mathrm{R}^{2}=0.93 ; \mathrm{NEI}, \mathrm{Y}=0.0034 \mathrm{x}-1.753, \mathrm{R}^{2}=0.90 ;$ LysI, $\mathrm{Y}=0.0122 \mathrm{x}-6.3532, \mathrm{R}^{2}=0.90$.

${ }^{* * *}$ Linear effect (Overall, 30 to $70 \mathrm{~kg}$ ): $\mathrm{ADG}, \mathrm{Y}=0.0003 \mathrm{x}+0.156, \mathrm{R}^{2}=0.91 ; \mathrm{FC}, \mathrm{Y}=-0.0008 \mathrm{x}+4.208, \mathrm{R}^{2}=0.86$; NEI, Y $=0.0024 \mathrm{x}-$ $0.292, \mathrm{R}^{2}=0.91 ;$ LysI, $\mathrm{Y}=0.0092 \mathrm{x}-0.602, \mathrm{R}^{2}=0.91$.

(QUINIOU \& NOBLET, 2012; MARÇAL et al., $2018 \mathrm{a}, \mathrm{b})$. However, this response was not observed in either of the phases in the present study.

Another hypothesis is that the difference between the evaluated NE levels (2.4 to $2.6 \mathrm{Mcal}$ $\mathrm{kg}^{-1}$ ) was sufficient to affect the ADFI of the pigs. A similar result was reported by KERR et al. (2003) who reported no effect of dietary NE levels ranging from 2.4 to $2.5 \mathrm{Mcal} \mathrm{Kg}^{-1}$ of diet for growing pigs ( 25 to $58 \mathrm{~kg}$ ).

The linear increase observed for NEI and LysI in phases 1 and 2 and in the overall period of the present study can be explained by the nutritional adjustments made in the diets to keep the calorie: nutrient ratio constant. Studies indicated that increasing the dietary NE level without maintaining the calorie: nutrient ratio result in a decrease in ADFI and an improvement in FC, with no effect on ADG and FW (GONÇALVES et al., 2015; MARÇAL et al., 2018a). Results of the present study is contrary to the studies cited, in which, regardless of the period evaluated, a linear increase in dietary NE was associated with increased ADG and FW. However, care is needed in practical situations when the dietary NE level is reduced, to avoid limited amounts of nutrients since diets containing very low energy densities can fill the gastrointestinal tract before meeting energy and 
Table 4 - Carcass characteristics of barrows from 30 to $70 \mathrm{~kg}$ fed with diets with different net energy levels.

\begin{tabular}{|c|c|c|c|c|c|c|c|c|}
\hline & - & -------.- & $\mathrm{s}, \mathrm{NE}(\mathrm{M}$ & 1) & - & ---------- & le-------- & $\mathrm{CV}, \%$ \\
\hline Variables & 2.40 & 2.45 & 2.50 & 2.55 & 2.60 & $\mathrm{~L}$ & Q & \\
\hline LEA, $\mathrm{cm}^{2}$ & 31.06 & 31.30 & 31.10 & 30.96 & 31.10 & 0.960 & 0.978 & 14.85 \\
\hline $\mathrm{MD}, \mathrm{mm}$ & 40.07 & 40.11 & 39.75 & 40.46 & 39.19 & 0.745 & 0.759 & 10.39 \\
\hline $\mathrm{BF}_{1}, \mathrm{~mm}$ & 3.37 & 3.97 & 3.40 & 3.19 & 3.98 & 0.616 & 0.586 & 26.32 \\
\hline $\mathrm{BF}_{2}, \mathrm{~mm}^{*}$ & 4.21 & 4.79 & 4.93 & 5.09 & 6.09 & 0.019 & 0.688 & 32.98 \\
\hline $\mathrm{BF}_{\mathrm{t}}, \mathrm{mm}$ & 7.58 & 8.76 & 8.33 & 8.28 & 10.07 & 0.060 & 0.614 & 27.17 \\
\hline Lean, \% & 59.61 & 58.93 & 59.15 & 59.24 & 58.08 & 0.081 & 0.599 & 2.60 \\
\hline BI & 103.87 & 102.52 & 103.37 & 103.65 & 103.02 & 0.752 & 0.721 & 2.29 \\
\hline
\end{tabular}

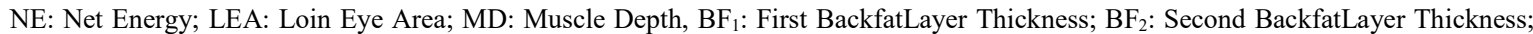
$\mathrm{BF}_{\mathrm{t}}$ : Total Backfat Thickness; BI: Bonification Index; L: Linear Effect; Q: Quadrtic Effect; CV: Coefficient of Variation.

*Linear effect: $\mathrm{BF}_{2} 70 \mathrm{~kg}, \mathrm{Y}=-15.278+0.008 \mathrm{x}$.

nutrient requirements, thereby impairing growth performance (AYMERICH et al., 2020).

During digestion, the presence of chylomicrons stimulates the release of apolipoprotein A-IV (apoA-IV) from jejunal cells (WANG et al., 2012). This substance acts together with other peptides (PYY, GLP-1, and OXM) to slow down gastric emptying and intestinal motility (TORRALLARDONA \& ROURA, 2009). Thus, an increase in lipid concentration in the diet can promote a lower rate of passage through the gastrointestinal tract and; consequently, increase the overall digestibility of the diet (KIL et al., 2011).

Considering the maintenance of the calorie:amino acids ratio in the evaluated diets, it can be inferred that diets with higher NE levels may provide greater input of energy and amino acids for protein synthesis, as well as longer time for action of enzymes on nutrients due to the deceleration of gastric emptying, which may have contributed to the linear improvement in ADG and FBW and; consequently, in $\mathrm{FC}$.

The $\mathrm{C}$ : $\mathrm{G}$ was not influenced $(\mathrm{P}>0.05)$ by dietary NE levels. Thus, it can be inferred that diets with higher NE and amino acids concentrations, even with a higher cost per kilogram of diet, resulted in similar costs when compared to those with lower nutritional concentrations, since there was a proportional improvement in the nutritional efficiency of these diets as the cost increased. This result could be attributed to the greater supply of energy and amino acids, which promoted greater efficiency in protein synthesis when compared to the lower NE level.

The highest NEI and amino acids intake did not result in increased protein synthesis, and consequently there were no statistical effects for the variables LEA, MD, lean, and BI. However, the pigs that consumed more energy and nutrients deposited more fat in the second layer of backfat $\left(\mathrm{BF}_{2}\right)$. The pigs probably did not increase protein deposition once their genetic potential was reached; and therefore, the nutrients ingested in excess were used for fat deposition.

The results obtained for $\mathrm{ADG}, \mathrm{FC}$, and FBW in the present study indicated that the ideal dietary NE level for barrows from 30 to $50 \mathrm{~kg}$ and from 50 to $70 \mathrm{~kg}$ is $2.60 \mathrm{Mcal} \mathrm{kg}^{-1}$. This result is higher than the recommendations of 2.48 Mcal of NE $\mathrm{kg}^{-1}$ for pigs from 25 to $75 \mathrm{~kg}$ (NRC, 2012) and 2.40 Mcal of NE kg-1 for pigs from 20 to $60 \mathrm{~kg}$ (FEDNA, 2013), and is also higher than the 2.50 and $2.54 \mathrm{Mcal}$ $\mathrm{NE} \mathrm{kg}{ }^{-1}$ levels established by ROSTAGNO et al. (2017) for pigs from 30 to $50 \mathrm{~kg}$ and from 50 to 70 $\mathrm{kg}$, respectively.

\section{CONCLUSION}

The dietary NE level of 2.60 Mcal $\mathrm{kg}^{-1}$ is recommended for barrows from 30 to $70 \mathrm{~kg}$, as it increases ADG, improves FC and does not affect feed cost, lean percentage, nor the bonification index of the carcass.

\section{ACKNOWLEDGMENTS}

The authors thank the Fundação de Apoio ao Desenvolvimento do Ensino, Ciência e Tecnologia do Estado de Mato Grosso do Sul (FUNDECT), Universidade Federal de Mato Grosso do Sul (UFMS), and Coordenação de Aperfeiçoamento de Pessoal de Nível Superior - Brasil (CAPES; Finance Code 001) for the financial support in the execution of the research project.

Ciência Rural, v.52, n.7, 2022. 
BIOETHICS

AND

COMMITTEE APPROVAL

BIOSSECURITY

The project was approved by the ethics committee in the use of animals, protocol number 957/2018, of the Universidade Federal de Mato Grosso do Sul (UFMS).

\section{DECLARATION OF CONFLICT OF} INTEREST

The authors declare no conflict of interest. The funding sponsors had no role in the design of the study; in the collection, analyses, or interpretation of data; in the writing of the manuscript, and in the decision to publish the results.

\section{AUTHORS' CONTRIBUTIONS}

All authors contributed equally for the conception and writing of the manuscript. All authors critically revised the manuscript and approved of the final version.

\section{REFERENCES}

AYMERICH, P. et al. The implications of nutritional strategies that modify dietary energy and lysine for growth performance in two different swine production systems. Animals, v.10, p.1638, 2020. Available from: <https://doi.org/10.3390/ani10091638>. Accessed: Oct. 20, 2020. doi: 10.3390/ani10091638.

BELLAVER, C. et al. Malt rootlets as ration ingredients for swine on growing and finishing stages. Radícula de malte na alimentação de suínos em crescimento e terminação. Pesquisa Agropecuária Brasileira, v.20, p.969-974, 1985. Available from: < https://ainfo. cnptia.embrapa.br/digital/bitstream/item/160468/1/Radicula-demalte-na-alimentacao-de-suinos-em-crescimento-e-terminacao. pdf $>$. Accessed: Mar. 20, 2020.

BUFFINGTON, D. E. et al. Black globe humidity index (BGHI) as comfort equation for dairy cows. Transaction of the American Society of Agricultural Engineers, v.24, p.711-714, 1981. Available from: <https://elibrary.asabe. org/abstract.asp?aid $=34325>$. Accessed: Feb. 17, 2021. doi: $10.13031 / 2013.34325$

CÁMARA, L. et al. Influence of net energy content of the diets on productive performance and carcass merit of gilts, boars and immunocastrated males slaughtered at $120 \mathrm{~kg}$ BW. Meat Science, v.98, p.773-780, 2014. Available from: $<$ https://doi.org/10.1016/j. meatsci.2014.07.025 > . Accessed: Mar. 20, 2020. doi: 10.1016/j. meatsci.2014.07.025.

FEDNA - Fundación Española para el Desarrollo de la Nutrición Animal. Necessidades nutricionales para ganado porcino normas Fedna. 2nd ed. 109p. 2013.

GONÇALVES, L. M. G. et al. Net energy levels for finishing barrows. Ciência Rural, v.45, p.464-469, 2015. Available from: $<$ https://doi.org/10.1590/0103-8478cr20131573>. Accessed: Mar. 20, 2020. doi: 10.1590/0103-8478cr20131573.

KERR, B. J. et al. Influence of dietary protein level, amino acid supplementation, and dietary energy levels on growing-finishing pig performance and carcass composition. Journal of Animal
Science, v.81, p.3075-3087, 2003. Available from: <https://doi. org/10.2527/2003.81123075x>. Accessed: Mar. 20, 2020. doi: $10.2527 / 2003.81123075 \mathrm{x}$

KIEFER, C. et al. Response of finishing swine maintained in different thermal environments. Revista Brasileira de Saúde e Produção Animal, v.11, p.496-504, 2010. Available from: $<$ https:// portalseer.ufba.br/index.php/rbspa/article/view/40250/22420>. Accessed: Mar. 20, 2020.

KIL, D. Y. et al. Net energy of soybean oil and choice White grease in diets fed to growing and finishing pigs. Journal of Animal Science, v.89, p.448-459, 2011. Available from: $<\mathrm{https}: / /$ doi.org/10.2527/jas.2010-3233>. Accessed: Mar. 20, 2020. doi: $10.2527 /$ jas.2010-3233.

LI, Q.; PATIENCE, J. F. Factors involved in the regulation of feed and energy intake of pigs. Animal Feed Science and Technology, v.233, p.23-33, 2017. Available from: < https://doi.org/10.1016/j. anifeedsci.2016.01.001>. Accessed: Mar. 20, 2020. doi: 10.1016/j. anifeedsci.2016.01.001

MARÇAL, D. A. et al. Dietary net energy plans for barrows from 25 to $100 \mathrm{~kg}$ body weight. Revista Brasileira de Zootecnia, v.47, p.e20180038. 2018a. Available from: <https://doi.org/10.1590/ rbz4720180038>. Accessed: Mar. 20, 2020. doi: 10.1590/ rbz4720180038.

MARÇAL, D. A. et al. Dietary net energy plans for gilts from 25 to $100 \mathrm{~kg}$ body weight. Revista Brasileira de Zootecnia, v.47, p.e20170341, 2018b. Available from: <https://doi.org/10.1590/ rbz4720170341>. Accessed: Mar. 20, 2020. doi: 10.1590/ rbz4720170341.

MARCAL, D. A. et al. Diet formulation method influences the response to increasing net energy in finishing pigs. Translational Animal Science, v.3, p.1349-1358, 2019. Available from: $<$ https:// doi.org/10.1093/tas/txz147>. Accessed: Mar. 20, 2020. doi: $10.1093 / \operatorname{tas} / \mathrm{txz} 147$

NITIKANCHANA, S. et al. Regression analysis to predict growth performance from dietary energy in growing-finishing pigs. Journal of Animal Science, v.93, p.2826-2839, 2015. Available from: <https://doi.org/10.2527/jas.2015-9005>. Accessed: Mar. 20, 2020. doi: $10.2527 /$ jas.2015-9005

NOBLET, J. Recent developments in net energy research for swine. In: Advances in Pork Production, v.18, p.149-156, 2007. University of Alberta, Edmonton.

NRC - National Research Council. Nutrient requirements of swine. ed. 11th ed. National Academy Press, Washington. 2012.

NYACHOTI, C. M. et al. Voluntary feed intake in growingfinishing pigs: A review of the main determining factors and potential approaches for accurate predictions. Canadian Journal of Animal Science, v.84, p.549-566, 2004. Available from: $<$ https://doi.org/10.4141/A04-001>. Accessed: Mar. 20, 2020. doi: 10.4141/A04-001.

QUINIOU, N.; NOBLET, J. Effect of the dietary net energy concentration on feed intake and performance of growingfinishing pigs housed individually. Journal of Animal Science, v.90, p.4362-4372, 2012. Available from: <https://doi.org/10.2527/ jas.2011-4004>. Accessed: Mar. 20, 2020. doi: https://doi. org/10.2527/jas.2011-4004. 
RENAUDEAU, D. et al. A meta-analysis of the effects of high ambient temperature on growth performance of growing-finishing pigs. Journal of Animal Science, v.89, p.2220-2230, 2011. Available from: <https://hal.inrae.fr/hal02646507/document>. Accessed: Mar. 20, 2020. doi: 10.2527/ jas.2010-3329.

ROSTAGNO, H. S. et al. Brazilian tables for poultry and swine: Food composition and nutritional requirements. 3th ed. Viçosa, MG. 2011.

ROSTAGNO, H. S. et al. Brazilian tables for poultry and swine: Food composition and nutritional requirements. 4th ed. Viçosa, MG. 2017.

TORRALLARDONA, D.; ROURA, E. Voluntary feed intake in pigs. Wageningen Academic Publishers, 365p. 2009.
SAKOMURA, N. K.; ROSTAGNO, H. S. Research methods in monogastric nutrition. 2.ed. Funep, Jaboticabal. 262p. 2016.

SAS - Statistical Analysis System. Version 9.1. Cary: SAS Institute Inc., 2004.

SMITH, M. N. et al. Feeding diets with reduced net energy levels to growing-finishing barrows and gilts. Canadian Journal of Animal Science, v.97, p.30-41, 2017. Available from: <https:// cdnsciencepub.com/doi/pdf/10.1139/cjas-2016-0045>. Accessed: Mar. 20, 2020. doi: 10.1139/cjas-2016-0045.

WANG, F. et al. Apolipoprotein A-IV improves glucose homeostasis by enhancing insulin secretion. Proceedings of the National Academy of Sciences, v.109, p.9641-9646, 2012. Available from: <https://doi.org/10.1073/pnas.1201433109>. Accessed: Mar. 20, 2020. doi: 10.1073/pnas.1201433109. 